\title{
In the Storm of COVID-19: College Students' Perceived Challenges With Virtual Learning
}

\author{
Lizhu Davis \\ California State University, Fresno \\ Qun Sun \\ California State University, Fresno \\ Todd Lone \\ California State University, Fresno
}

\author{
Annette Levi \\ California State University, Fresno \\ Pei Xu \\ California State University, Fresno
}

\begin{abstract}
Using open-ended questions, this study surveyed over 450 undergraduate students to gain insights into their perceptions of the virtual learning environment due to the COVID-19 pandemic. Results reveal the rapid transition of most courses to online teaching because of COVID-19 was very challenging for students. A conceptual model was developed on the challenges of virtual learning. The findings reveal three major challenges for virtual learning: learning environment, motivation, and learning effectiveness. Environment and personal characteristics contributed to the lack of motivation to learn. Furthermore, students' learning behavior and professors' unpreparedness, and subject matter caused decreased learning effectiveness. The findings of the study can help decision makers at colleges and universities make informed decisions when adopting and/or modifying different teaching/learning environments, as well as professors in developing effective teaching strategies and pedagogy.
\end{abstract}

Keywords: synchronous, asynchronous, virtual learning, online

\section{INTRODUCTION}

Today, it is not uncommon for students to participate in online learning as part of their degree requirements. As technology advances and student lifestyles evolve, colleges and universities continue to offer additional "flexible" student-centered learning environments (Kemp \& Grieve, 2014). Student preferences between the two primary modes of instruction of face-to-face and online vary. Students preferring face-to-face instruction are more comfortable in a familiar, traditional classroom setting where 
distractions from the home environment do not hinder their concentration. Those preferring online learning like the independence it provides and are most likely more self-directed to assume the responsibility for their learning. This self-directed learning behavior contributes to the potential benefits of online learning such as encouraging student participation, producing more in-depth discussions, and improved quality of learning, while being more cost effective for institutions when compared to face-to-face learning (Smith \& Hardaker, 2000; Alexander, 2001).

The COVID-19 pandemic necessitated that higher education transition from face-to-face to virtual instruction during March and April of 2020 to help students finish the educational term while minimizing further spread of the virus. The practice of virtual instruction continued for many of these institutions through the spring 2021 term and has continued at certain levels during the fall of 2021 with the new outbreak of COVID from new variants. Before the onset of the pandemic, many students had no prior experience with online learning and suddenly were faced with a difficult decision; adapt to this new style of learning or interrupt their education until after the pandemic. For many, the virtual learning environment presented a host of new challenges to successfully learning course material and staying on track to graduate. As virtual learning continued, educational institutions and agencies surveyed students to determine those challenges as well as students' attitudes about the virtual learning environment. For example, in a survey of 40,000 college students from 118 universities, the EDUCAUSE Center for Analysis and Research discovered 70 percent of students prefer face-to-face classes (Gierdowski, 2019).

This pandemic has prompted changes in people's lifestyles and how businesses operate, and some of these changes will persist after the pandemic is over. Thus, it is not unreasonable to assume that higher education will maintain and/or build upon what was learned during the hastened implementation of a virtual learning environment. For example, innovative practices that work in this virtual environment can most likely be adapted to improve learning effectiveness in both face-to-face and online courses. But a vital part of improving both environments is to understand how various aspects of the recent virtual instruction period were perceived by students as contributing to, or distracting from, their learning. Such knowledge can benefit higher education in numerous ways: 1) helping to further identify what motivates students in the learning process, 2) expanding the knowledge base of innovative teaching practices, 3) identifying areas of pedagogical training for faculty, etc.

Although many studies have investigated online education pedagogy, more research is needed to understand the impact of a fully online education environment, as was just experienced by students, faculty, and administration. A key question becomes whether this mode of education is sustainable or effective from a student's perspective. Therefore, the purpose of this study is to understand in-depth students' learning experiences, especially their perceived challenges with a fully virtual learning environment as a result of the rapid transition to virtual learning. For the purpose of this study, virtual courses refer to all courses taught online, including synchronous ones, asynchronous ones, and those with both synchronous and asynchronous components. Synchronous courses are assumed to be conducted live online, while an asynchronous course has pre-recorded lectures and materials. In some asynchronous courses the material may be completely self-paced and independent where students can access the online materials at any time, while synchronous online learning allows for real time interaction between students and the instructor. This study uses a combination of forced choice and open-ended questions to better understand what students liked and disliked about the 100 percent virtual learning environment that was imposed during the pandemic. Besides understanding the challenges of the virtual learning environment, this study also focused on understanding the reasons behind each challenge. A conceptual model on virtual learning was developed based on the findings of the study. The findings of the study can help: 1) decision makers at colleges and universities make informed decisions when adopting and/or modifying different teaching/learning environments and 2) professors in developing effective teaching strategies and pedagogy. 


\section{LITERATURE REVIEW}

\section{Theoretical Framework - Learning Theories and Social Learning}

The college years are a critical period in students' lives. Students achieve personal, social, and intellectual growth and develop into mature, responsible and independent adults (Pascarella \& Terenzini, 2005). Although universities/colleges offer enriching academic and social programs and foster students' growth, it is still not easy for some students to succeed in college. Based on Shapiro et al. (2005), only about $60 \%$ of students received a bachelor's degree or its equivalent within six years.

Most universities/colleges recognize the value of students' institutional commitment, which has been studied by several researchers. For example, Bean and Vesper (1990) developed Student Integration and Student Attrition Models. They (Bean \& Vesper, 1990) found more committed students tend to have better grades and graduate in a timely manner. Davidson, Beck, and Grisaffe (2015) developed ten validated indexes of institutional commitment and associated psychosocial attributes and used them to test their relationship to institutional commitment. Results revealed academic integration, social integration, and degree commitment had direct effects on students' institutional commitment; meanwhile, cognitive ability such as "Motive to Learn " is important for student success in college. Other studies have attributed students' learning behavior to cognitive predictors such as self-efficacy, meta-cognitive knowledge, and goal progress (Lent et al., 2014; Sheu, Chong, Chen \& Lin, 2014). Students with high levels of self-efficacy take initiative in learning and enjoy the learning process (Tims, Bakker \& Derks, 2014).

To provide high quality education, it is critical to understand students' needs and motivations. Deci and Ryan (2000) developed a self-determination theory (SDT), which unites six categories of motivational regulations, ranging from amotivation to self-determined forms of motivation and integrated them into a single organizational scheme. The study revealed (2000) three basic needs of students are competence, relatedness, and autonomy. Another study of 1,257 students at two 4-year universities found a strong link between these three needs and their commitments to the university and to obtaining a degree (Davidson, 2019). Other studies confirmed that these three student needs have a big impact on students' learning performance and perceived enjoyment (Lee, Cheung \& Chen, 2005; Pe-Than, Goh \& Lee, 2014). Specifically, competence enables people to seek out the challenges that best suit their abilities and persist in maintaining and improving these skills and abilities through activities (Deci \& Ryan, 2000). Competence positively influences students' comfort with mobile-based learning technologies (Nikou \& Economides, 2017). Sorebo, Halvari, Gulli and Kristiansen (2009) found that competence benefits students' perceived usefulness and intrinsic motivation. Deci and Ryan (2000) reported that relatedness refers to feeling connected with others, loving, and caring for others, being loved and cared by others. Researchers found that people with perceived relatedness to have a sense of belongingness with other individuals and are more likely to be motivated and engaged in learning. Deci and Ryan (2000) also stated that autonomy is an important aspect of human health. It refers to being the perceived origin or source of one's own behavior.

\section{Empirical Studies of Online Learning - Benefits and Challenges}

Online learning is education that takes place over the internet when a teacher and students are separated by a physical distance (McVay, 2000). Due to advances in computer and Internet technology, online courses have grown the fastest in all levels of higher education. It attracts more and more students from traditional education services. In fall 2018, there were 6,932,074 (35.3\%) U.S. college students who took a distance education course (De Brey, Snyder, Zhang, \& Dillow, 2019). Online learning has many advantages for institutions, students, and instructors. It can potentially reduce school costs while giving students flexibility (Bartindale, 2013), which is especially beneficial for students who have full-time work and part-time school obligations. Online learning systems also reduce the time and space limitations of instruction found in traditional in-person classes (Allen \& Seaman, 2007). These online platforms are capable of engaging students with course content and accommodating various learning modalities, just like face-to-face instruction. The online learning management systems such as BlackBoard, Canvas, and WebBoard provide instructors with an increased range of instructional techniques and options. Instructors can closely monitor 
student progress and provide timely feedback while e-mail, discussion boards and chat rooms promote interactive learning (Robson, 2002).

Although the drive to online instruction continues to grow, there are some potentially troubling issues. Students taking online courses generally fall behind academically, especially for less academically prepared students (Alpert, Couch \& Harmon, 2016). Other observational studies relied on larger samples of students using fixed effects models, instrumental variables, or other methods. Shifting courses from in-person to online affected student academic progress in college, from lower grades to reduced course enrollment at the university (Bettinger, Fox, Loeb \& Taylor, 2017; Hoxby, 2015; Xu \& Jaggars, 2014). Math, humanities, and social science courses are the most affected by online enrollment, while information technology-based courses are not affected (Hart, Friedmann \& Hill, 2018). However, some studies found that achievement of learning outcomes was not significantly different between face-to-face versus blended instruction (Alpert et al., 2016; Joyce, Crockett, Jaeger, Altindag, \& O'Connell, 2015) and purely online versus blended instruction (Bowen, Chingos, Lack, \& Nygren, 2014). The results showed there was no significant difference in learning performance in terms of pass rate, the final exam and a standardized test between the two teaching formats, and a blended teaching model can also reduce the cost of teaching resources.

Online learning performance is also influenced by students' abilities to use computer-related technologies (Bandura, 1997). DeLoughery (1993) indicated that as many as one-third of college students suffer from technophobia, or fear of using new technology. In a teaching university, freshmen who took computing courses were more likely to feel reality shock, confusion, control attempts, anger and more likely to withdraw from these courses than other courses (Sproull, Zubrow, \& Kiesler, 1986). The learning outcome became much worse when students were required to use a variety of online learning technologies but were not trained adequately in their use. The students' online learning performance can be improved if they believe that they have the capacity to use the technology and are willing to spend time to learn it. The concept of internet self-efficacy was proposed by some researchers (Compeau \& Higgins, 1995). Students with high internet self-efficacy are more motivated to learn in online courses, which improves their academic performance (Wang \& Newlin, 2002; Potosky, 2002). Those with a high sense of self-efficacy perform well on examinations and easily achieve their learning goals (Chang et al., 2014; Salanova, Grau, Cifre, \& Liorens, 2000). In addition, the support of teachers, peers, and family members, as well as the sense of belonging in the community, are other factors that contribute to the success of online learning. Vayre and Vonthron (2017) revealed that social support provided by teachers had a big impact on students' course involvement, and the sense of community in online learning was a significant direct predictor of students' engagement.

\section{Empirical Studies on COVID-19 and the Sudden Transition to Virtual/Remote Learning}

Coronavirus disease 2019 (COVID-19) is a novel infectious virus that has had adverse effects on a global scale. Due to prolonged pandemic conditions, lockdowns and stay-at-home orders, the COVID-19 pandemic has had a negative impact on college students. Nearly twenty million U.S. college students have had their psychological well-being, academic and life outcomes affected by the pandemic (Association of American Colleges and Universities News, 2021).

\section{Academic Learning}

The negative effect on students' academic performance by shifting to online instruction during the COVID-19 pandemic was found by several studies. Research shows that neither students nor teachers were prepared for the sudden changes. Quality Matters, a nationally recognized leader in online learning, conducted a survey in May 2020 in which 308 chief online officers (COOs) from different universities in the U.S. participated in the survey. Respondents said half of the teachers had no previous online teaching experience and could not cope with this challenge, and $75 \%$ of the teachers did not have the ability to switch to online teaching, while $62 \%$ of students were not well prepared for online learning (Garrett, Legon, Fredericksen, \& Simunich, 2020). A national survey of undergraduates during the pandemic confirmed the sudden change posed challenges for students; only $19 \%$ of students were "very satisfied" after switching to online instruction and achievement of learning outcomes were less positive (Means \& Neisler, 2020). 
Another study explored 270 college students' perceptions of online learning using quantitative and qualitative methodologies (Patricia Aguilera-Hermida, 2020). The findings showed that learning motivation, self-efficacy, and cognitive engagement decreased since courses transitioned to online, and only the use of technology increased. This situation was worse for students who could not get access to digital learning tools such as smartphones and the internet (United Nations Inter-Agency Network on Youth Development, 2020). Still another study found undergraduate students experienced more frustration, perceived less engagement during online learning, and it was challenging for them to finish all their courses (Parker, Hansen, \& Bernadowski, 2021). In addition, during the COVID-19 pandemic, many countries placed restrictions on immigration, which had a big influence on students. A survey conducted by (Quacquarelli Symonds, 2020) on global higher education during the pandemic found that $47 \%$ of the students have changed their plan to pursue a degree in foreign countries due to travel restrictions and admission examination cancellations.

\section{Mental Health}

Many studies have shown that during the COVID-19 pandemic, students face higher levels of anxiety, depression, suicidal thoughts and behaviors. Schaeffer and Rainie (2020) found that young people between the age of 18-29 years are more prone to mental trauma and stress due to social isolation and financial crises. Herold and Chen (2020) revealed the stress level of 65\% of students significantly increased and 57\% of students had limited ability to focus during the pandemic. Patsali et al. (2020) studied 1,104 women

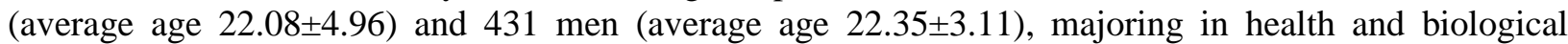
sciences, technical sciences and art, literature, education and related sciences. Major findings due to the lockdown include: 1) increased anxiety was reported by all participants, 2) compared with men, women's risk of depression was twofold, 3) it had a higher impact on students of technical sciences and arts, literature, education and related sciences, and 4) $30 \%$ of students experienced physical illness. Another study reported that more students increased their use of alcohol or marijuana during the pandemic, $22.1 \%$ and $10.2 \%$, respectively (Association of American Colleges and Universities News, 2021). The sudden shift from an offline (face-to-face) to online mode of teaching because of the pandemic has created a burden in the form of personal adjustments (International Institute for Higher Education in Latin America and the Caribbean, 2020). First, students' work life was disrupted. Many of them returned to their homes and are living in social isolation. Second, students were forced to move towards the online paradigm while dealing with financial issues such as student loans, the decline in scholarships, loss of job, etc. (DePietro, 2020). Furthermore, examination delays and barriers to learning led to student stress (Roy et al., 2020). The results of these studies emphasize the urgent need to develop intervention and prevention strategies to solve the mental health problems of college students (Son, Hegde, Smith, Wang \& Sasangohao, 2020).

In summary, there have been extensive studies of college students' learning behavior and its relationship to academic performance. But for emergency remote teaching due to the COVID-19 pandemic, researchers mostly focused on college students' mental health. There is a shortage of studies on what the specific factors are in influencing college students' learning motivation during the COVID-19 pandemic. In the post-COVID era, the expansion of online teaching will be a possibility due to varied educational innovations, opening online teaching to more learners. The continuing challenge facing instructors is how to improve online teaching design, teaching methods and delivery models to attract students and achieve learning outcomes. The findings from this study may help instructors better understand the reasons behind poor learning motivation under a hastily implemented online instruction environment and help instructors to consider new strategies to deliver education in a feasible and effective way moving forward.

\section{METHODOLOGY - DATA COLLECTION PROCESS}

An online Qualtrics survey of students was conducted in several agriculture virtual courses during the fall 2020 and spring 2021 semesters. Students voluntarily completed the online questionnaire, knowing they would not receive bonus points nor other grade incentives. To minimize the chance of a student taking the survey in more than one course, care was taken to avoid administering the survey in multiple courses 
that students typically take concurrently during a semester, and students were specifically requested and reminded not to complete the survey more than once during the academic year.

The unexpected and prompt change from 100 percent face-to-face teaching to virtual instruction motivated this study. A total of 17 questions were asked in the survey. The first section gathered demographic information (age, gender, race) and academic standing (GPA, major, year in college). The second section asked students to use a Likert scale to rate their level of agreement with positive and negative statements about virtual learning. Finally, the third section asked three open-ended questions regarding what students liked the most and the least about virtual instruction, along with any other comments about the virtual learning experience. A total of 449 students responded during the 2020/21 academic year, 177 in fall 2020 and 272 in spring 2021.

The goal of the third section of open-ended questions was to further understand the benefits and challenges of virtual learning from the students' perspective. The literature shows that: 1) using open-ended questions as part of the online survey not only helps respondents to explain their thoughts but also provides large amounts of data to use (Lang \& Liu, 2019), and 2) using open-ended questions to fill qualitative methods is effective in uncovering valuable insights, experiences and perspectives that are difficult to obtain from other research methods (Creswell, 2012). In this study the response rate from the open-ended questions was high, with $90 \%$ of respondents answering the open-ended question for what they liked about virtual learning, 94\% mentioned what they disliked, and $69 \%$ gave additional comments about virtual learning. Students freely shared an in-depth opinion about challenges they faced and benefits they perceived during virtual learning.

\section{General Demographics}

Table 1 presents the demographic information of the student respondents. The sample contains slightly more males (52\%) than females (47\%). In terms of ethnicity, $46 \%$ of the students are Hispanic, $46 \%$ white, and $4 \%$ Asian. Typical university age groups are represented in the sample, with those less than 20 years of age the largest group (24\%), 20 years (21\%), 21 years (19\%), 22 years (13\%), and 23+ years (23\%). One-third of the students have two to three years of work experience, nearly $36 \%$ more than four years, $16 \%$ one year, and $15 \%$ no work experience.

TABLE 1

STUDENTS' DEMOGRAPHIC PROFILE

\begin{tabular}{|l|l|l|l|l|c|}
\hline Survey Variable & Count & Percentage & Survey Variable & Count & Percentage \\
\hline & & & & & \\
\hline Gender & & & Ethnicity & & \\
\hline Female & 211 & 47 & American Indian & 7 & 2 \\
\hline Male & 235 & 52 & Asian & 19 & 4 \\
\hline Other & 1 & 0 & Black/African American & 4 & 1 \\
\hline Missing & 2 & 0 & Hispanic & 207 & 46 \\
\hline Total & 449 & 100 & White & 205 & 46 \\
\hline & & & Other & 7 & 2 \\
\hline Age & & & Total & 449 & 100 \\
\hline Less than 20 & 108 & 24 & & & \\
\hline 20 & 95 & 21 & Work Experience & 65 & 15 \\
\hline 21 & 83 & 19 & None & 73 & 16 \\
\hline 22 & 58 & 13 & 1 Year & 150 & 33 \\
\hline $23+$ & 105 & 23 & 2 - 3 Years & 88 & 20 \\
\hline Total & 449 & 100 & 4 - 5 Years & 73 & 16 \\
\hline & & & 6+ Years & 449 & 100 \\
\hline
\end{tabular}




\section{Other Characteristics of Participants}

Table 2 shows the results regarding academic standing. Juniors (40\%) and seniors (28\%) make up the majority of the respondents, followed by sophomores (15\%), freshman (14\%), and graduate students (3\%). The top three majors represented are agricultural business (61\%), enology and viticulture (13\%), and animal science (5\%). Expected graduation percentages are 2021 (35\%), $2022(28 \%)$, and 2023 or later (21\%).

\section{TABLE 2 ACADEMIC STANDING}

\begin{tabular}{|c|l|l|l|l|l|}
\hline Survey Variable & Count & Percentage & Survey Variable & Count & Percentage \\
\hline & & & & & \\
\hline Survey Semester & & & Year of Graduation & & \\
\hline Spring 2020 & 272 & 61 & 2020 & 54 & 12 \\
\hline Fall 2020 & 177 & 39 & 2021 & 156 & 35 \\
\hline Total & 449 & 100 & 2022 & 125 & 28 \\
\hline & & & 2023 & 79 & 18 \\
\hline Graduation Status & & & 2024 & 15 & 3 \\
\hline Freshman & 63 & 14 & Not Sure & 20 & 5 \\
\hline Sophomore & 68 & 15 & Total & 449 & 100 \\
\hline Junior & 179 & 40 & & & \\
\hline Senior & 125 & 28 & Predominant Majors & & \\
\hline Graduate Student & 14 & 3 & Agricultural Business & 272 & 61 \\
\hline Total & 449 & 100 & Enology \& Viticulture & 57 & 13 \\
\hline & & & Animal Science & 23 & 5 \\
\hline Estimated GPA & & & Agricultural Education & 18 & 4 \\
\hline $1.00-1.99$ & 1 & 0 & Plant Science & 16 & 4 \\
\hline $2.00-2.99$ & 105 & 23 & Other & 48 & 11 \\
\hline $3.00-4.00$ & 316 & 70 & Missing & 15 & 3 \\
\hline Not Sure & 25 & 6 & Total & 449 & 100 \\
\hline Missing & 2 & 0 & & & \\
\hline Total & 449 & 100 & & & \\
\hline
\end{tabular}

\section{Qualitative Data Analysis}

Content analysis was used to analyze the data collected through the open-ended questions. Content analysis enables making "replicable and valid inferences from texts (or other meaningful matter) to the contexts of their use" (Krippendorff, 2004, p.18). Several cycles of part-to-whole interpretive procedures were conducted to organize the raw data and to generate conceptual schemes based on the data (Spiggle, 1994). The coding standard was developed by one researcher to ensure a consistent data set was expressive of the qualitative information collected.

\section{FINDINGS}

The data reveal three major perceived challenges of virtual learning: 1) learning environment, 2) motivation, and 3) learning effectiveness. Furthermore, participants' personal factors, professors' readiness, and subject matter affect students' learning effectiveness. Table 3 illustrates the major categories of contextual findings related to the challenges of virtual learning. 
TABLE 3

CHALLENGES OF VIRTUAL LEARNING

\begin{tabular}{|c|c|c|c|c|c|}
\hline Themes /Categories & Count & $\%(n=414)$ & Themes /Categories & Count & $\%(n=414)$ \\
\hline Learning Environment & & & Personal Factors & & \\
\hline Distractions /Focus & 67 & 16 & Time Management & 25 & 6 \\
\hline $\begin{array}{l}\text { Communication } \\
\text { Challenges }\end{array}$ & 81 & 20 & Learning Style & 24 & 6 \\
\hline $\begin{array}{l}\text { Engagement/ } \\
\text { Interaction/ Sense of } \\
\text { Community }\end{array}$ & 79 & 19 & & & \\
\hline $\begin{array}{l}\text { Technology, } \\
\text { including Internet }\end{array}$ & 27 & 7 & Subject Matter & 34 & 8 \\
\hline \multirow[t]{2}{*}{ Motivations } & 25 & 6 & Faculty Preparedness & & \\
\hline & & & Technology & 10 & 2 \\
\hline Learning Effectiveness & & & $\begin{array}{l}\text { Pedagogy/ Teaching } \\
\text { Strategies }\end{array}$ & 63 & 15 \\
\hline Group Projects & 29 & 7 & Increased Assignment & 15 & 4 \\
\hline $\begin{array}{l}\text { Hard to Learn/ } \\
\text { Understand }\end{array}$ & 70 & 17 & & & \\
\hline
\end{tabular}

\section{Learning Environment}

The virtual learning environment was very challenging for many students. Barriers associated with learning at home include distractions, isolation, difficulty in communication, and unavailability of needed technology, such as weak Wi-Fi connection.

Distractions and technology. Most students took their courses from home where they may not have an ideal learning environment. With the presence of other family members, pending housework and other responsibilities, participants frequently cited being distracted and found themselves having a hard time focusing on studying and learning (16\% of responses). As one participant commented "there are more distractions in the home than in the classroom" and it can be "extremely hard" to focus on learning, especially for long periods of time. Other examples of student responses regarding this issue include, "It is hard for me to focus in my zoom classes when I am stuck in my apartment all day." and "It was a lot harder for me to focus on school when I am at home with lots of other things to do than school."

Compared with the home learning environment, on campus and in-person class meetings help some students to better focus on learning. For example, one participant commented, "I get easily distracted, forget about assignments, and do not pay attention as well as I would in a face-to-face meeting." Another said, "I hate not being able to study on campus. I need somewhere to do work and focus. It's hard for me to focus at home." Furthermore, about $7 \%$ of the comments discussed the challenges caused by a lack of proper technology such as not being able to get laptops/tablets and an unstable internet connection.

\section{Isolation and Communication}

With "shelter-in-place," "quarantine," and "lockdown," COVID-19 created a very isolated learning environment. Some participants (19\%) expressed their frustrations with the lack of "connections with peers and professors," "contact" with others, "social interaction" and the "sense of community." Based on social learning theory (Bandura, 1977), individuals learn from observing others' behavior and the outcomes of those behaviors. Therefore, social environments and interpersonal relationships are important to promote learning. The loss of social interaction may cause learning difficulties, especially in the absence of social skills and behavioral cues. As one participant stated, "[I did not like the fact] that I didn't have one-on-one 
contact with the professor. I'm more engaged when I'm in class." Other students noted, "[I did not like] not having a sense of community and not being able to exchange ideas and thoughts with classmates." and "I did not enjoy not having face-to-face interaction and losing the sense of a class community." Being isolated from peers and instructors, effective communication became very challenging for some participants (20\%). They commented on "less communication," "lack of communication," and "no" communication, and disliked not being able to talk with their professors and classmates face-to-face. In addition, it was difficult to get instant feedback when relying solely on remote communications.

\section{Motivation}

A few participants $(6 \%)$ revealed that they were less motivated during virtual learning and lost motivation for attending class, completing assignments, and became uninterested in learning; they found it "difficult" and "challenging" to get motivated. Both the learning environment and personal characteristics contributed to the loss of motivation. And being at home without a formal learning environment can make it even more difficult to be involved in learning. For example, one participant stated, "I feel really unmotivated. Virtual learning is not on the same level compared to face-to-face learning. I love attending school and getting the feel of the campus environment and online school has been miserable." Another participant explained, "[Virtual learning] makes you lack motivation and since you are in your comfort zone, it's easy to get lazy." Still another participant shared, "I used to study and finish all of my work at the library because everyone was studying and therefore it gave me motivation to finish."

Some participants were not motivated because they "did not like looking at a screen listening to someone talk." Other participants (6\%) claimed that they are hands-on learners and learn better in a faceto-face environment. For them, the lack of hands-on experiences contributed to the lack of motivation. Some participants believed virtual learning was not feasible and it was also a painful experience, as one shared, "I have become incredibly depressed and unmotivated overall because of online virtual learning."

\section{Learning Effectiveness}

Taking all of their courses virtually prevented some participants from learning effectively. Participants stated $(17 \%)$ that it was more difficult to learn and/or understand some course materials and concepts in online and virtual meetings. As one participant expressed, "I struggled extremely with understanding the course content." while another stated, "I feel that I am not learning anything through this." The data reveal that several factors contributed to ineffective learning, including the learning environment, personal factors, the subject matter, and the degree of faculty preparedness.

\section{Learning Development}

Distractions, difficulty in communications, and loss of social interactions all affected learning effectiveness. When participants were distracted because of taking classes at home, they felt unable to focus on learning. For example, one participant stated, "I had a harder time learning because I was at home rather than in the classroom where there are no distractions." Similarly, another participant said, "It's easy to get distracted being home and virtual learning seems to be harder [for me] to understand some contexts."

Some participants revealed that it was extremely challenging to work on team projects, which made it challenging to learn and accomplish assignments on time. The key issue with a group assignment is communication and some participants found it difficult to communicate online (remotely) or during zoom meetings to get the group project done. For example, one participant stated, "[I did not like] how hard it is to communicate for group projects online through just zoom or facetime. Learning is generally harder." Another student wrote, "I least liked how hard it was to communicate with other students, such as doing a group project." A key element that was not always recognized by all students is that virtual learning requires students to take initiative and meet outside of class to collaborate on assignments. However, participants found "It was often difficult to get my group members to work on class projects if we were not using class time." Additionally, some students do not communicate effectively and timely with their teammates. One participant pointed out that "some students do not put the effort in to even answer a basic email." Another one claimed "Group members were unresponsive in many classes." One participant was so frustrated with 
group projects because of the lack of communication, stating. "Sometimes they (group mates) leave you in the dark which causes assignments to be late."

Furthermore, the lack of social connection and interaction with peers makes it even more difficult to communicate and collaborate on assignments. One participant had two group projects which had been "extremely difficult to accomplish because of such little connection between teachers and students." Another participant believed that virtual learning "reduces the interactions with other students in class which affects the group discussions. It's hard to work together as a group when you can't see the person" or when you "did not really get a chance to meet everyone." In addition, students not having the normal faceto-face opportunities to meet and know each other made it challenging to form groups. As one student said, "Not being able to meet people face-to-face prevented me from creating strong study groups and support systems." Overall, participants believed it was more effective to work on group projects and have group discussions with in-person learning, commenting that group projects are "an in-person activity." Since they "couldn't meet up or ever work together in person," it made group projects, as a whole, difficult. Therefore, participants "prefer face to face when doing these types of activities."

\section{Personal Factors}

From a personal perspective, some participants $(6 \%)$ found it was difficult to learn virtually because of their own time management and organizational skills. Without "the set daily schedule" and the routine of going to school and attending classes, some students had a hard time getting organized. While some were able to "prioritize my time and make a point to participate in zoom meetings," others were not as successful in this aspect of learning. Some participants stated that they "keep forgetting when assignments are due," "constantly worry about an assignment that was due," and it was difficult to "keep up to date on assignments," and "keep track of assignments."

Personal learning style was another key factor that emerged from the data. Results revealed that some participants $(6 \%)$ were "hands-on" and "visual" learners. For those participants, learning online or virtually is not effective, learning in person is more beneficial. For example, participants shared, "I am a hands-on learner; therefore, Zoom hasn't been the most beneficial" and "I didn't like having to move classes to virtual. As a visual hands-on person, [I need] to be present in class to understand the concepts. [It] has been harder and at a faster pace than what it was in class." Another participant claimed, "I am a hands-on learner so not being able to learn that way was extremely challenging." For those participants, face-to-face learning is viewed as much more efficient and effective.

\section{Subject Matter}

Besides hands-on learning, students believed (8\%) some subjects and courses such as labs and practicum courses need personal and hands-on experiences. They believed online and virtual learning prevents them from learning deeply and accurately by doing and observing. For example, one participant reflected, "It also makes hands-on classes such as labs much more difficult and students do not get the intended learning out of the course." Another said, "My classes are very hands-on, and I haven't learned much since [the campus switched to virtual learning]."

Learning goes beyond discussing basic concepts and principles, it also includes skills development. Participants believe that without practice in a physical location with appropriate equipment, it is impossible to learn specific skills. For example, one student commented, "What I like least about virtual instruction is not being face to face in class and [this] prevents you from doing certain labs where you do hands-on work in the industry." Another student noted, "my major is largely based on hands-on experiences to which virtual learning does nothing for."

Not being able to learn most effectively was especially frustrating for graduating seniors. They felt that they were cheated, as expressed by one participant who stated, "I had a class that had an experiment on the school farm regarding nitrogen management in lettuce and I feel like I could have learned a lot more in person. It is really hard to view the deficiency symptoms in plants virtually and impossible to take soil samples virtually. I honestly feel cheated and that I may leave college with a disadvantage in the workforce. That is NOT how this is supposed to be." It is clear from this survey that many students preferred to have 
face-to-face instruction for those kinds of classes. As one student reflected, "it is better to learn face to face because some material is harder to show on a screen (ex:labs)."

\section{Faculty Preparedness}

Participants' learning effectiveness was also affected by the degree of faculty preparedness. Before the pandemic, the majority of instructors taught face-to-face courses. The sudden transition to teaching virtually, especially during mid semester, made it very challenging for some instructors. Some students commented that their instructors did not know how to use technology. As one student remarked, "Some of my professors don't know how to use technology very well so we always run into complications." In addition, faculty did not always have appropriate equipment and technology to demonstrate during zoom meetings. Some students observed that, "zoom settings make it difficult for professors to draw on the board," and "some professors do not do well in explaining online." Another commented, "Some professors wanted to do so much but there is a limitation in a virtual class."

Virtual learning requires adaptation of teaching styles and strategies. At the same time, many faculty members were not trained on online teaching pedagogy and strategies. One student observed, "Virtual learning made it hard to fully understand the material, especially since some of my professors did not know how to continue class online." Another student interpreted faculty's inability to deliver course content virtually as "unwilling to change how they taught the course." Similarly, another commented, "One of my professors did not handle it very well and seemed to not make an effort to handle it better."

Other students $(4 \%)$ commented on sudden changes in the type and number of assignments, noting some professors did not "follow the same guidelines," and "gave busy work." More importantly, since there was no university standard on virtual delivery, faculty members across campus adopted different strategies, which can be confusing for students. As one student stated, "Not every teacher sets up their web based learning the same. Some of my professors have zoom meetings during normal 'class' hours while others just [offered] recorded lectures and set up weekly modules. It was difficult to get into a learning rhythm because I didn't feel motivated to attend the regularly scheduled classes when I could do other classes at my pace."

\section{Motivation}

Motivation is critical for effective learning. As mentioned above, some students lost their motivation for learning. One student shared, “Zoom classes have also made it difficult to keep up and really don't motivate me. They might be useful for someone who prefers online classes but physical classes are where I learn best." This sentiment was voiced by others as well, "I feel really discouraged, unmotivated; and it really has brought me down academically." and "I am not learning [having] classes online. there's no motivation to get work done." and "It's kind of difficult to maintain the motivation to study."

\section{DISCUSSION}

The findings of this study reveal that a 100 percent virtual learning environment can be very challenging for some college students. The negative effect of suddenly switching to pure online learning was confirmed by several studies (Bettinger et al., 2017; Hoxby, 2015; Xu \& Jaggars, 2014). Some students complained about a distractive learning environment at home which makes it difficult to maintain focus. Others mentioned the lack of communication and social interaction, and its impact on their learning. For those reasons, some students lost their motivation for learning. This is consistent with previous studies of the importance of support from teachers, peers, and family members, as well as the sense of belonging in the community, to the success of online learning (Vayre \& Vonthron, 2017).

Due to a variety of factors, students were frustrated with the inefficiency of learning in this virtual environment. In addition to the factors discussed earlier, students cited personal factors, subject matter, and the degree of faculty preparedness as contributing to their ineffective learning. Virtual learning is very challenging for "hands on" learners who learn better by active participation and application. Creating a virtual learning environment to provide such activities requires time, training, and resources that many 
faculty were not afforded during the hastened switch to virtual learning. For some agricultural courses that are lab intensive, such as viticulture, winemaking and food analysis, it is challenging to achieve similar learning outcomes without access to physical farm fields, winery facilities and laboratories. Students feel strongly that those courses need an in-person environment to effectively learn special skills.

This study's findings reveal that students believe virtual learning is better suited for certain disciplines and subject matters in which discussions are the main mode of teaching and learning, rather than hands-on experiments requiring specialized equipment, outdoor surroundings, or face-to-face contact. This could be a factor helping explain why De Brey, Snyder, Zhang and Dillow (2021) found that Business/Management, Computer/Information, and Education are leading the switch to online courses. Furthermore, both students and faculty were significantly affected by virtual learning. Previous research has shown that to be successful, students have to be self-motivated, have time management and organizational skills, be proficient in technology, and be prepared for, or familiar with, online education pedagogy. They also have to have access to a good learning environment. On the other hand, students in this study indicate that faculty members who teach virtual courses have to be technologically savvy, properly trained in online pedagogy, have the ability to engage students well in the online environment, and have excellent communication skills.

Based on data obtained in this study, a conceptual model was developed to illustrate the challenges of virtual learning (see Figure 1). The model shows that students' motivation to learn is affected by a learning environment defined by: 1) the ability to focus and avoid distractions, 2) the presence of communication and interaction with peers and faculty, and 3) the technological requirements of virtual learning. The importance of the learning environment is also confirmed by Yang, Peng, Wong and Chong (2017), after surveying 377 college students who participated in e-learning and found that perceived closeness, perceived control, and peer referents all had a positive impact on self-efficacy, wellness of students, and enhanced students' enthusiasm for e-learning. This model also demonstrates that personal factors such as a student's preference for specific learning modalities and effective time management skills both increased students' motivation to learn. The opinions expressed by students in this study indicate overcoming the challenges presented by the learning environment, motivation, personal factors, subject matter, and instructor preparedness will all help the effectiveness of virtual learning.

\section{CONCLUSIONS AND IMPLICATIONS}

Although online teaching is not a novelty, the COVID-19 pandemic took it to a new level, one in which some campuses moved to almost 100 percent online teaching for an extended period. As the number of COVID-19 cases in the United States subsides, the economy reopens, and people return to their "normal" lives, many universities will go back to "normal," face-to-face instruction. But what about the teaching practice that has a heavy reliance on virtual instruction and learning? Will universities embrace it, or treat it as an anomaly? If it is embraced more fully, how should it be modified and implemented? To answer these questions, this study surveyed students who were forced into an entirely online teaching environment to hear about their perceptions regarding the effectiveness of online versus face-to-face learning.

Based on results from this study, students believe the rapid transition of most courses to online teaching during the COVID-19 pandemic is very challenging. They identified three major challenges facing emergency implementation of virtual learning:1) the home learning environment, which was less than ideal, caused distractions, and was lack of proper technology, social isolation and insufficient communication, 2) learning environment and personal characteristics both contributed to the lack of motivation to learn, and 3) a series of factors including students' learning behavior and professors' unpreparedness caused low motivation to learn. Students also believed that courses with laboratory and hands-on experience were most affected. 
FIGURE 1

CHALLENGES OF VIRTUAL LEARNING

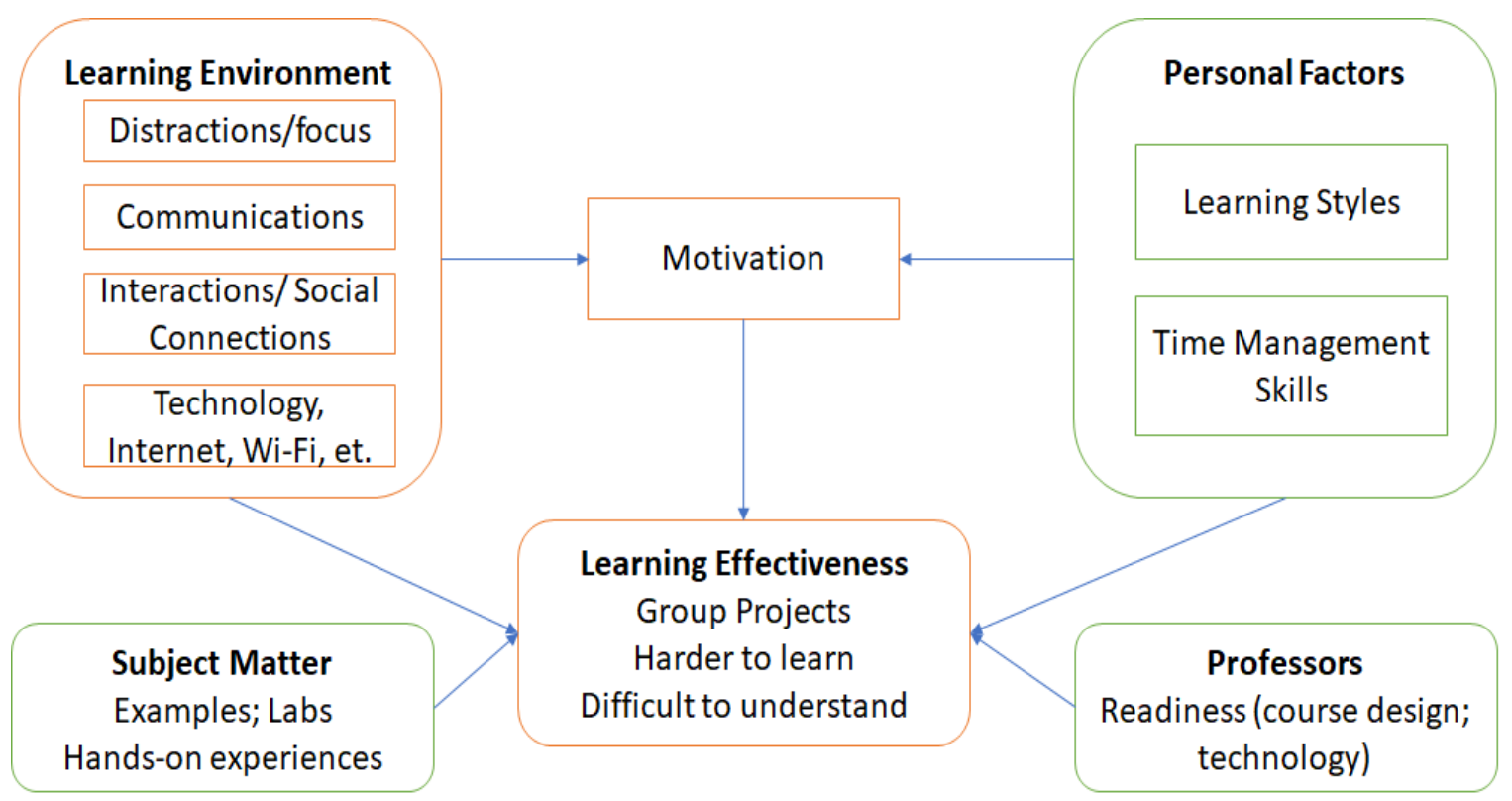

The pandemic also prompted universities and colleges to explore different educational strategies. Currently, some universities are pushing hard on limiting virtual learning after its heavy use during the pandemic and are emphasizing traditional face-to-face as a more effective learning environment. However, it can be argued that virtual teaching is very valuable to higher education, especially for some majors, and should be embraced by universities. First, with advances in technology, online teaching can be very effective. For example, synchronous online teaching using platforms such as Zoom can be effective when it comes to getting students engaged and creating social interaction among students. Second, it can benefit institutions by recruiting qualified part-time instructors to teach remotely. This is especially important for small specialty programs that face tremendous challenges hiring qualified instructors due to resource constraints. With virtual teaching and learning, those programs can serve their students in a more costefficient manner. Third, virtual teaching has the potential of enhancing collaboration between academic programs and industry partners. For example, virtual learning has made it easier to incorporate guest speakers and conduct advisory board meetings.

The bottom line is not losing sight of the purpose of education, which is about applying different methods and pedagogy to help students learn effectively. High quality education should constantly evolve with new technologies, new ideas, and innovations while maintaining flexibility for both faculty and students. It is important to remember that virtual learning may not be as effective for all courses and students. Analysis of the data from this study reveal that the learning environment students are confronted with profoundly affects learning effectiveness. Thus, as campuses reopen with face-to-face classes, the learning environment challenges of virtual learning will be addressed for many students. When students are able to come to campus, they may: 1) take advantage of study spaces while taking virtual and face-to-face classes to avoid the distractions they tend to have at home, 2) meet with friends and peers for communication and social interaction, and 3) use free Wi-Fi and equipment on campus.

To improve the effectiveness and value of virtual learning, the findings of this study address the following areas. First, there should be a clear definition of virtual instruction and how virtual classes are conducted, for students and instructors. Because of the flexibility granted to faculty in the COVID-19 virtual teaching model on many campuses, faculty conducted their virtual courses in different ways. Some required synchronous class meetings as scheduled, some met synchronously for a portion of the scheduled class meetings, and some set up their courses as asynchronous online classes. This led to confusion among 
students and a loss of motivation. Knowing what to expect and how to proceed can help students and faculty set clear expectations and help maintain the quality of learning effectiveness in virtual classes. Second, faculty teaching virtual classes should be proficient in appropriate teaching pedagogy. While much research has been conducted on virtual learning and resources exist to help prepare faculty and students for the virtual learning environment, continuing education for faculty can enhance the quality of the learning experience for students. According to the conceptual model developed in this study, new strategies can be utilized to improve students' learning effectiveness. Examples include, creating a better learning environment, enhancing student interaction, training instructors through workshops, and improving students' computer-based technology and soft skills such as adaptability, time management, critical thinking, collaboration and problem solving. The new information gained by listening to students' concerns may be used to modify existing practices to mitigate the impact of the challenges they perceive and thus improve the virtual learning experience. If modified accordingly and implemented effectively, virtual classes will continue to benefit both the university and students, and supplement face-to-face courses.

\section{REFERENCES}

Aguilera-Hermida, P. (2020). College students' use and acceptance of emergency online learning due to COVID-19. International Journal of Educational Research Open, 1(100011).

Alexander, S. (2001). E-learning developments and experiences. Educational Training, 43, 240-248.

Allen, E., \& Seaman, J. (2007, October). Online nation: Five years of growth in online learning. Bayview Analytics. Retrieved from https://bayviewanalytics.com/reports/online-nation.pdf

Alpert, W., Couch, K., \& Harmon, O. (2016). A randomized assessment of online learning. American Economic Review, 106(5), 378-382.

Bakker, A.B., \& Demerouti, E. (2014). Daily job crafting and the self- efficacy-performance relationship. A Complete Reference Guide, Editors PY Chen and CL Cooper, pp. 1-28.

Bandura, A. (1977). Social Learning Theory. Englewood Cliffs, N.J.: Prentice-Hall.

Bartindale, B. (2013, November 13). Foothill-DeAnza to lead \$16.9m statewide Online Education Initiative: Statewide effort aims to increase degree attainment and university transfers. Inside Higher Ed. Retrieved from https://www.insidehighered.com/sites/default/server_files/files/OEIPressReleaseFinal\%20(1).pdf

Bean, J.P., \& Vesper, N. (1990). Quantitative approaches to grounding theory in data: Using LISREL to develop a local model and theory of student attrition. Annual Meeting of the American Educational Research Association.

Bettinger, E., Fox, L., Loeb, S., \& Taylor, E. (2017). Virtual classrooms: How online college courses affect student success. American Economic Review, 107(9), 2855-2875.

Bowen, W., Chingos, M., Lack, K., \& Nygren, T. (2014). Interactive learning online at public universities: Evidence from a six-campus randomized trial. Journal of Policy Analysis and Management, 33(1), 94-111.

Chang, D., Liu, E., Sung, H., Chen, N., \& Cheng, S. (2014). Effects of online college student's Internet self-efficacy on learning motivation and performance. Innovations in Education and Teaching International, 51(4), 366-377.

CMIE. (2020). Unemployment rate in India. Retrieved from https://unemploymentinindia.cmie.com/ Compeau, D., \& Higgins, C. (1995). Application of social cognitive theory to training for computer skills. Information Systems Research, 6, 118-143.

Cresswell, J.W. (2012). Qualitative inquiry and research design: Choosing among five approaches. Sage Publications, Inc.

Davidson, W., \& Beck, H.P. (2018). Analyzing the Commitment of College Students Using a Brief, Contextualized Measure of Need Satisfaction from the Perspective of Self-Determination Theory. Psychological Reports, 122(3), 1145-1166. https://doi.org/10.1177/0033294118769452 
Davidson, W.B., Beck, B., \& Grisaffe, D.B. (2015). Increasing the institutional commitment of college students: Enhanced measurement and test of a nomological model. Journal of College Student Retention: Research, Theory \& Practice, 17(2), 162-185.

deBrey, C., Snyder, T., Zhang, A., \& Dillow, S. (2021, February). Digest of Education Statistics 2019 (55th Edition). NCES 2021-009. ERIC. Retrieved from https://eric.ed.gov/?id=ED611019

Deci, E.L., \& Ryan, R.M. (2000). The "what" and "why" of goal pursuits: Human needs and the selfdetermination of behavior. Psychology Inquiry, 11, 227-268.

DeLoughery, T. (1993). Two researchers say " "technophobia"' may afflict millions of students. Chronicle of Higher Education, pp. A25-A26.

DePietro, A. (2020, April 30). Here's a look at the impact of coronavirus (COVID-19) on colleges and universities. In The U.S. Forbes. Retrieved from https://www.forbes.com/sites/andrewdepietro/2020/04/30/impact-coronavirus-covid-19-collegesuniversities/?sh=19837f9f61a6

Dinther, M.V., Dochy, F., \& Segers, M. (2011). Factors affecting students' self- efficacy in higher education. Educational Research Review, 6, 95-108.

Figlio, D., Rush, M., \& Yin, L. (2013). Is it live or is it internet? Experimental estimates of the effects of online instruction on student learning. Journal of Labor Economics, 31(4), 763-784.

Garrett, R., Legon, R., Fredericksen, E., \& Simunich, B. (2020). CHLOE 5: The pivot to remote teaching in Spring 2020 and its impact. Quality Matters.

Gierdowski, D. (2019, October 30). 2019 Study of Undergraduate Students and Information Technology. EDUCAUSE. Retrieved from https://library.educause.edu/resources/2019/10/2019-study-ofundergraduate-students-and-information-technology

Hart, C., Friedmann, E., \& Hill, M. (2018). Online course- taking and student outcomes in California Community Colleges. Education Finance and Policy, 13(1), 42-71.

Herold, D., \& Chen, T. (2020). Switching From Face-to-Face to Online Instruction Midsemester: Implications for Student Learning. Journal of Teaching and Learning With Technology, 10, 321336.

Hoxby, C. (2015). Online postsecondary education and labor productivity. In C. Hulten \& V. Ramey (Eds.), Implications for future U.S. GDP growth (Vol. 77, pp. 410-460). University of Chicago Press.

IANYD. (2020). UN Inter-Agency Network on Youth Development. Retrieved from https://www.un.org/development/desa/youth/what-we-do/un-inter-agency-network-on-youthdevelopment.html

Institute of education sciences. (2021, February). Digest of education statistics 2019 (NCES 2021-009).

National center for education statistics. Retrieved from https://nces.ed.gov/pubs2021/2021009.pdf

Joyce, T., Crockett, S., Jaeger, E., Altindag, O., \& O’Connell, S. (2015). Does classroom time matter? Economics of Education Review, 46, 64-77.

Krieg, J., \& Henson, S. (2016). The educational impact of online learning: How do university students perform in subsequent courses? Education Finance and Policy, 11(4), 426-448.

Krippendorff, K. (2004). Content Analysis: An Introduction to Its Methodology. Sage Publications, Inc., 2nd ed.

Lang, C., \& Liu, C. (2019). The entrepreneurial motivations, cognitive factors, and barriers to become a fashion entrepreneur: A direction to curriculum development for fashion entrepreneurship education. International Journal of Fashion Design, Technology and Education. https://doi.org/10.1080/17543266.2019.1581844

Lee, M.K., Cheung, C.M., \& Chen, Z. (2005). Acceptance of internet-based learning medium: The role of extrinsic and intrinsic motivation. Information and Management, 42(8), 1095-1104.

Lent, R., Taviera, M.C., Pinto, J.C., Silva, A.D., Blanco, A., Faria, S., \& Gonçalves, A.M. (2014). Social cognitive predictors of well-being in African college students. Journal of Vocational Behavior, 84, 266-272. 
McVay, M. (2000). How to be successful distance learning student: Learning on the internet (second edition). Pearson custom publishing.

Means, B., \& Neisler, J. (2020). Suddenly online: A national Survey of undergraduates during the COVID-19 pandemic. Digital Promise.

Nenaugh, K., \& Grieve, R. (2014). Face-to-face or face-to-screen? Undergraduates' opinions and test performance in classroom vs. online learning. Frontiers in Psychology, 5(1278).

Nikou, S.A., \& Economides, A.A. (2017). Mobile-based assessment: Integrating acceptance and motivational factors into a combined model of self-determination theory and technology acceptance. Computers in Human Behavior, 68, 83-95.

Parker, S., Hansen, M., \& Bernadowski, C. (2021). COVID-19 Campus Closures in the United States: American Student Perceptions of Forced Transition to Remote Learning. Social Science, 10(62).

Pascarella, E.T., \& Terenzini, P.T. (2005). How college affects students: A third decade of research. Jossey-Bass, 2.

Patsali, M., Mousa, D., Papadopoulou, E., Papadopoulou, K., Kaparounaki, C., Kakogiannis, I., \& Fountoulakis, K. (2020). University students' changes in mental health status determinants of behavior during COVID-19 lockdown in Greece. Psychiatry Research, 292(113298).

Pe-Than, P.P.E., Goh, D.H.L., \& Lee, C.S. (2014). Making work fun: Investigating antecedents of perceived enjoyment in human computation games for information sharing. Computers in Human Behavior, 39, 88-99.

Potosky, D. (2002). A field study of computer efficacy beliefs as an outcome of training: The role of computer playfulness, computer knowledge, and performance during training. Computer in Human Behavior, 18, 241-255.

Roca, J.C., \& Gagne, M. (2008). Understanding e-learning continuance intention in the workplace: A self-determination theory perspective. Computers in Human Behavior, 24, 1585-1604.

Roy, D., Tripathy, S., Kar, S., Sharma, N., Verma, S., \& Kaushal, V. (2020). Study of knowledge, attitude, anxiety \& perceived mental healthcare need in Indian population during COVID-19 pandemic. Asian Journal of Psychiatry, 51(102083).

Salanova, M., Grau, R., Cifre, E., \& Llorens, S. (2000). Computer training, frequency of usage and burnout: The moderating role of computer self-efficacy. Computers in Human Behavior, 16, 575590.

Schaeffer, K., \& Rainie, L. (2020). Experiences with the COVID-19 outbreak can vary for Americans of different ages. Pew Research Center. Retrieved from https://www.pewresearch.org/facttank/2020/06/16/experiences-with-the-covid-19-outbreak-can-vary-for-americans-of-differentages/

Shapiro, D., Dundar, A., Wakhungu, P.K., Yuan, X., Nathan, A., \& Hwang, Y. (2015). Completing college: A national view of student attainment rates-Fall 2009 cohort (Signature Report No. 10). National Student Clearinghouse Research Center.

Sheu, H.B., Chong, S.S., Chen, H.F., \& Lin, W.C. (2014). Well-being of Taiwanese and Singaporean college students: Cross-cultural validity of a modified social cognitive model. Journal of Counseling Psychology, 61, 447-460.

Smith, D., \& Hardaker, G. (2001). E-learning innovation through the implementation of an Internet supported learning environment. Education Technology Society, 3, 1-16.

Son, C., Hegde, S., Smith, A., Wang, X., \& Sasangohar, F. (2020). Effects of COVID-19 on college students' mental health in the United States: Interview survey study. Journal of Medical Internet Research, 22(9).

Sørebø, Ø., Halvari, H., Gulli, V.F., \& Kristiansen, R. (2009). The role of self-determination theory in explaining teachers' motivation to continue to use e-learning technology. Computers and Education, 53, 1177-1187.

Spiggle, S. (1994). Analysis and Interpretation of Qualitative Data in Consumer Research. Journal of Consumer Behavior, 21(3), 491-503. 
Sproull, L., Zubrow, D., \& Kiesler, S. (1986). Cultural socialization to computing in college. Computers in Human Behavior, 2, 257-275.

Tims, M., Bakker, A.B., \& Derks, D. (2014). Daily job crafting and the self- efficacy-performance relationship. Journal of Managerial Psychology, 29, 490-507.

UNESCO and IESALC. (2020). COVID-19 and higher education: Today and tomorrow. Impact analysis, policy responses and recommendations.

Vayre, E., \& Vonthron, A. (2017). Psychological engagement of students in distance and online learning: Effects of self-efficacy and psychosocial processes. Journal of Educational Computing Research, 55(s), 197-218.

Wang, A., \& Newlin, M. (2002). Predictors of web-student performance: The role of self-efficacy and reasons for taking an on-line class. Computers in Human Behavior, 18, 151-163.

Xu, D., \& Jaggars, S. (2014). Performance gaps between online and face-to-face courses: Differences across types of students and academic subject areas. Journal of Higher Education, 85(5), 633659.

Yang, J., Peng, M.Y., Wong, S.H., \& Chong, W.L. (2021). How E-Learning Environmental Stimuli Influence Determinates of Learning Engagement in the Context of COVID-19? SOR Model Perspective. Frontiers in Psychology, 12. https://doi.org/10.3389/fpsyg.2021.584976 